\title{
Predicting Publication Prices
}

\section{Are the Old Models Still Relevant?}

\author{
Pamela Bluh, James G. Neal, and J. Randolph Call
}

The three brief articles here are based on presentations given in June 2002 at the Annual Conference of the American Library Association in Atlanta at a program sponsored by the ALCTS Committee on Library Materials Cost Index, titled "Predicting Publication Prices: Are the Old Models Still Relevant?"-Editor

\section{Predicting Publication Prices: Introduction Pamela Bluh}

For many years, the library community has maintained an exceptional and persistent interest in monitoring price increases for library materials; during periods of economic uncertainty or recession, this topic takes on added significance. In 1957, perhaps in response to market conditions in the late 1950s, an ad hoc Committee on Cost of Library Materials Index was established. Its members spent the next two years developing a methodology to predict publication prices for the library community, and in 1959 the committee shed its ad hoc designation and became a standing committee of the Acquisitions Section of the Resources and Technical Services Division, the forerunner of the Association for Library Collections and Technical Services, a division of the American Library Association. The initial members of this committee were James W. Henderson (New York Public Library), William H. Kurth (National Library of Medicine), who served as chair, Sidney E. Matthews (Ohio State University), Frank L. Schick (U.S. Office of Education), Helen Welch (University of Illinois Library), and Avis Zebker (Brooklyn Public Library). They were responsible for assembling the pricing information, which first appeared in Library Journal (Kurth 1960).

This modest beginning paved the way over the years for additional cost studies and, in 1965, a name change to Library Materials Price Index Committee to more closely reflect the group's activities. The committee's succinct charge, "to prepare and publish price indexes of library materials," gives it considerable freedom and flexibility. Over the years, the composition of the committee has increased and so, too, has the number of price indexes for which it is responsible.

As with any venerable group, the Library Materials Price Index Committee has struggled from time to time with questions about its role and the relevancy of its activities. Several of the indexes seem to be in a state of limbo, and recent difficulties in the subscription agent community have raised concerns about the timeliness with which the data can be obtained, as well as the future of the indexes in general. The meteoric rise of e-journals and the overabundance of 
acquisitions models for e-journals are making price predictions much more complicated. The current dire economic outlook is one more factor to be considered as the question of the relevancy of the committee's current and future work is examined.

The convergence of all these factors precipitated discussion among members of the committee about whether the price indexes, as they are presently constituted, still provide useful information and whether they are worth continuing. Could external factors signal the demise of the price indexes? Should new methodologies for tracking prices be explored? How could prices for electronic publications be handled? Has the time come to "retire" some of the indexes permanently? What might the role of the committee be with regard to preparation and publication of the price indexes in the future?

To search for answers to these fundamental questions, the committee sponsored a program in June 2002 at the Annual Conference of the American Library Association in Atlanta titled "Predicting Publication Prices: Are the Old Models Still Relevant?" at which presentations by two librarians (published in this issue of LRTS), an economist, and a vendor examined the role of price indexes in various settings in an effort to shed light on their relevancy in today's marketplace. Mark McCabe, Assistant Professor of Economics, Georgia Institute of Technology, has done considerable work for both the Association of Research Libraries and the American Association of Law Libraries to analyze the trends that influence publishers and ultimately result in increased publication prices. Information about his research and publications can be found at his Web site at www.prism.gatech.edu/ mm284.

The vendor's perspective, as reported by Tina Feick, Vice President, Customer Service, Swets Blackwell, Inc., touched on the business considerations that influence price increases. She noted that traditional factors such as inflation, the rising cost of paper and production services, the rate of exchange of the U.S. dollar against foreign currency, and the introduction of the Euro, often blamed for rising prices, are rapidly being overshadowed by the intense desire for access to electronic data and the confusion this shift creates for standard price prediction models.

The two papers presented here represent the library point of view on the value of the price indexes. James Neal explains how pricing data should be used together with other information to generate realistic budget expectations and assessments. In academe, the budget-planning process is as much a practical matter as it is a political one, and the use of price indexes may help to confer a degree of authority to the budgeting process. R. Randolph Call draws on his experience in budget planning in a large urban public library and offers comments about the nature of the planning process and the value of the published indexes in the public library setting.
Libraries approach the budget-planning process in different ways, and they use the price indexes in different ways as well. Exclusive reliance on the price indexes is a thing of the past. Libraries now use these indexes in conjunction with a variety of other tools and other sources of information. In order to achieve the level of credibility and reliability the published indexes had in the past, they will require some changes. The methodology may need to be tweaked, and the indexes must become more nimble so that they can respond quickly to market vacillations. In their present form, the price indexes are most valuable when combined with other sources of pricing data because they endow the budget-planning process with a degree of authority. With some modifications, and with the development of tools to track and predict prices for electronic resources, price indexes will continue to provide a useful service.

\section{Works Cited}

Brogan, Martha, comp. 2002. Core Library Materials' Price Indexes and Surveys. Accessed Aug. 9, 2003, www.indiana. edu/ libcodev/CoreLibraryMaterials.doc.

Kurth, William H. 1960. U.S. book and periodical prices: A preliminary report. Library Journal 85 (1): 54-57.

\section{Predicting Publication Prices: An Academic Library Perspective James $\mathbf{G}$. Neal}

Publication price indexes are an integral part of the collection budgeting process in the academic library. Indexes support the core objectives for preparing the collection budget: to satisfy the information needs of academic priorities and to respond effectively to market trends. Indexes enable the creation of budget models and help to define budget roles and responsibilities among director, collection development staff, and committees. Indexes link to budget inputs - the creation and formulation of the financial plan, and to budget outputs- the allocation and implementation of expenditures. Indexes are political tools, serving to influence behaviors and decisions on the collection budget. Indexes are integral to budget presentations, communicating authoritative information to both internal and campus audiences.

Are publication price indexes still relevant in the context of important trends and developments? Such developments may include the expanding investment in electronic resources, not tracked by the standard indexes; the increasing bulk licensing versus the purchase and ownership of publications; the recognition that quality is influenced by content and functionality; the growing importance of consortial rather than institutional purchasing; innovative and 
diverse models of scholarly publishing and communication; the record of expanding investment in serials subscriptions at the expense of book acquisitions; and the impact of retrospective and foreign buying.

Forecasting is both a science and an art. A forecast is a prophecy, estimate, or prediction of a future happening or condition. An index is a ratio derived from a series of observations used as an indicator or measure. Probability is the chance that a given event will occur. What confidence do we have in chance, observations, and prophecies in managing the collection development process?

The results from an informal online survey conducted in the spring of 2002 with 55 academic research and liberal arts college libraries indicate that budget planners use multiple sources in developing a budget. They do not rely solely on published indexes, but also take very close notice of a number of additional factors, including institutional price history, publisher-produced data, vendor-produced data, Association of Research Libraries data, and consortium price history, in developing a budget.

How do academic library leaders use price indexes? Based on the survey input, the following applications were identified as important:

- to influence campus administrative support

- to strengthen campus budget presentations

- to analyze library purchasing power

- to plot trends and plan budgets

- to provide support for new academic programs

- to educate faculty and secure their support

- to assist with journal cancellation projects

- to influence state budget agencies

- to value collections for insurance purposes

- to support asset accounting for collection discards

- to determine charges for lost books

- to assist with the training of new selectors

What concerns do academic library leaders have about price indexes? Based on the survey input, the following objections were raised:

- currency

- accuracy

- local relevance

- usability

- acceptance

- level of detail

- coverage of world areas

- coverage of nonbook and electronic media

- coverage of interdisciplinary fields

- applicability to diverse institutional settings

- absence of standards

- acceptability by a new generation of selectors
Publication price indexes present an important continuum of usability as a tool for collection development and fiscal decisions. Are indexes primarily political, communication, planning, budgeting, or allocation tools? In most academic library settings, all of these uses apply, but with varying levels of relevance and confidence.

\section{Predicting Publication Prices: A Public Library Perspective \\ J. Randolph Call}

In the public library environment, the answer to the question "are the old methods for predicting publication prices still relevant?" is "yes," but with some equivocation. The old familiar tools now appear to play only a minor role in the budgeting process. In order to understand how the public library factors price information into its budgeting process, one could look at the procedures used at the Detroit Public Library (DPL) as an example of how public libraries deal with price increases.

The Detroit Public Library is one of the oldest and largest public libraries in the United States, first opening its doors in 1865 (Woodford 1965). The Detroit Public Library System consists of a main library and twenty-three branches, serving the citizens of Detroit as well as providing services to residents throughout the state of Michigan. In 2001-2002, the library collection consisted of more than 7.5 million volumes including approximately 4.5 million federal depository items. The library is not a unit of the city of Detroit or any other local jurisdiction in the state of Michigan, rather it is an independent municipal corporation with its own taxing authority and, as such, it may differ radically from most other public libraries whose budgets are established by the municipalities in which they are located.

Regardless of how the funding is obtained, a public library's budget is derived primarily from tax revenue. Particularly in large urban areas, populations have been declining, resulting in a shrinking tax base and less revenue. In some cities, changing economic conditions may not only have caused property values to decrease, but simultaneously also may hamper the ability of some citizens to pay their taxes. Consequently, the library's budget is prone to fluctuate dramatically from one fiscal year to the next.

The annual budget-planning process usually begins nine to ten months prior to the beginning of the fiscal year. In Detroit, where the fiscal year begins on July 1, the initial planning phase begins in the fall and usually lasts three to four months, during which time sources of revenue are identified. The library is required to submit a balanced budget, so anticipating changes in revenue and projecting income is frustrating and challenging. The budget-planning cycle 
includes several preliminary or draft budgets and, in extreme circumstances, the library may even begin a new fiscal year without having received its final operating budget.

DPL determines its budget by prioritizing needs and by keeping close tabs on changing sources and levels of revenue. The priorities are established during the budget-planning process and the competition for funds is fierce. Maintaining the materials budget is extremely important. Equally important is maintaining the physical infrastructure in an aging, urban library system, which requires constant improvement to the physical plant. Funds to replace or upgrade technology and telecommunications also are urgently needed, as are funds to absorb ongoing expenditures for services financed initially through grants or by donations.

The library's focus, first and foremost, in this process is on the materials budget and on ensuring that sufficient funds are allocated to maintain the collection of periodicals, serials, and standing orders. In one year, library materials may be budgeted at 6 percent of the total budget and, in the following year, the budgeted amount may go as high as 10 percent. Securing an adequate allocation for library materials often varies widely from year to year, and the percentage allocated for library materials rarely remains steady for two consecutive years, making planning and collection development extremely problematic.

In order to gauge the amount of money needed, budget planners examine not only revenue estimates, but also study price prediction tools for serials and periodicals. The most reliable tools for this purpose are the periodical and serial price studies previously published annually in Library Journal, then in American Libraries, and now in Library Resources and Technical Services. Each study reports multiple analyses and, by comparing that data with the data developed in-house by library staff, the relevance of the published price predictions can be confirmed. From the public library perspective, a useful component of these prices studies is each study's variant of U.S. periodical and serial titles most often subscribed to by public and school libraries.

These two annual studies are used to project the funding that will be required to maintain the library's current print and microform subscriptions and standing orders. That information is compared to the proposed materials allocation outlined in the budget drafts. Based on that comparison, decisions are made whether there are sufficient funds to handle the proposed increases, whether cuts will be required, or whether additional funding might be available.
Budgeting for traditional print publications is done, in part, by using established price prediction tools, but as libraries move more heavily into the provision of access to electronic databases and full-text data files, the price indexes are losing their primacy. Predicting price increases for electronic data is still very much experimental and is much more complicated than developing predictions for print materials because many more variables must be considered. As a result, predicting prices for electronic resources frequently is based on anecdotal evidence as well as on market intelligence, otherwise known as rumors, gleaned from online discussion lists, from reviews of the professional literature, and from contact with colleagues. To borrow from the vernacular, predicting prices for electronic journals is a "craps shoot."

The bulk of the library's budget is earmarked for serials, standing orders, and other ongoing commitments and, as a result, funds for monographic material are extremely limited. Price predictions for monographic material published in the Bowker Annual: Library and Book Trade Almanac are only useful in a theoretical sense, since budgets based on those predictions are routinely rejected very early in the planning process simply because the resources are insufficient to meet the budget estimates. As a result, the library no longer uses price prediction tools to help develop a budget estimate for monographic material and makes do with whatever funds remain after allocations for ongoing commitments have been made.

In the public library, as in the academic library, published price prediction tools play a less significant role today than they have in the past. While the information is interesting from a theoretical standpoint, it has become less valuable in practice as libraries grapple with a wide variety of influences and considerations in planning their budgets. When funds flowed freely, predictions of price increases based on published data were given considerable credence. When revenue is inadequate to keep up with the library's needs and when traditional collections are in decline in favor of nontraditional resources, traditional price prediction tools are only one means of many that must be employed to design and achieve a reasonable budget.

\section{Work Cited}

Woodford, Frank B. 1965. Parnassus on Main Street. Detroit: Wayne State Univ. Pr. 